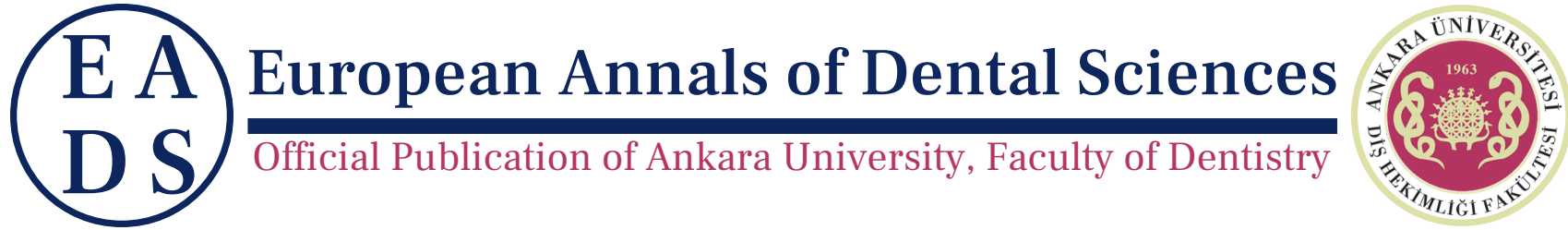

EADS, 2021, 48 (2), 78-83

\title{
Treatment Management With Long Term Follow-Up In Late-Admitted Traumatized Permanent Incisors:
} Case Series

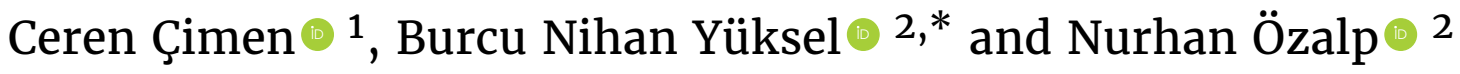 \\ ${ }^{1}$ DDS, Department of Pediatric Dentistry, Faculty of Dentistry, Ankara University, Ankara, Turkey and ${ }^{2}$ DDS, \\ $\mathrm{PhD}$, Department of Pediatric Dentistry, Faculty of Dentistry, Ankara University, Ankara, Turkey \\ *Corresponding Author; bncelik@ankara.edu.tr
}

\begin{abstract}
Traumatic dental injuries are particularly common in school-age children and often occur in the anterior region. Process management of cases is possible with alternative treatments according to the root development levels. This case series is aimed to present the treatment and 2-year follow-up of permanent anterior teeth with traumatic dental injuries. Case 1: An 8-year-old patient, who had a bicycle accident 20 days earlier, was diagnosed with extrusion of \#31. Due to late admission to the clinic, no repositioning procedure was applied to the tooth. Regenerative endodontic treatment was performed. During the radiological follow-up, the apex was closed in the $12^{\text {th }}$ month; however, it was observed that obliteration started in the root canal at the $24^{\text {th }}$ month. The case is still being followed up at regular intervals. Case 2: A 13-year-old patient, who had a traffic accident 3 days prior, was diagnosed with subluxation in \#11, and a root fracture was detected in the apical third of \#21. In \#21, root canal treatment was applied to the coronal part of the fragments. After the diagnosis of pulp necrosis in \#11 in the $2^{\text {nd }}$ month of the follow-up period, root canal filling was applied. During the follow-up period, no pathology was detected and no granulation tissue was formed between the fragments in \#21.

In traumatic dental injuries, long-term follow-up, well-timed endodontic treatments, and material selection play an important role in success. With regenerative endodontic treatment, successful results can be obtained even in treatments applied in late-admitted patients.
\end{abstract}

Key words: delayed treatment; dental trauma; extrusion; regenerative endodontic treatment; root fracture; subluxation

\section{Introduction}

Traumatic dental injuries (TDI) are one of the public health problems that affect primary and permanent teeth, especially in children and adolescents. Although the prevalence of TDI varies depending on gender, socioeconomic level and environmental factors, ${ }^{1}$ they tend to occur more often between the ages of $7-12^{2}$ and approximately $25 \%$ of school-age children in permanent dentition experience TDI. 3,4 The most frequently affected teeth are the upper central incisors, followed by the lateral incisors and lower incisors. ${ }^{1,5}$

Traumatic dental injuries are classified as types of traumas on

(i) hard tissue and pulp,

(ii) periodontal tissues, (iii) supportive bone,

(iv) gingiva and oral mucosa. ${ }^{6}$

Subluxation has been defined as the loosening of the tooth due to damage of periodontal ligament (PDL); but displacement is not observed clinically and radiographically. ${ }^{7}$ Due to the damage of the neuro-vascular supportive tissue of the pulp, various undesirable consequences may occur after subluxation. ${ }^{1}$ The studies revealed that symptoms such as discoloration, canal obliteration or root resorption may be observed over time. ${ }^{8,9}$ Pedrini et al. ${ }^{10}$ reported that $69 \%$ of 68 teeth with pulp necrosis were diagnosed within the first 3 months after subluxation injury. Extrusion is characterized by the partial axial displacement of the tooth from the socket. The mobility of the tooth increases with partial severance of PDL attachment 

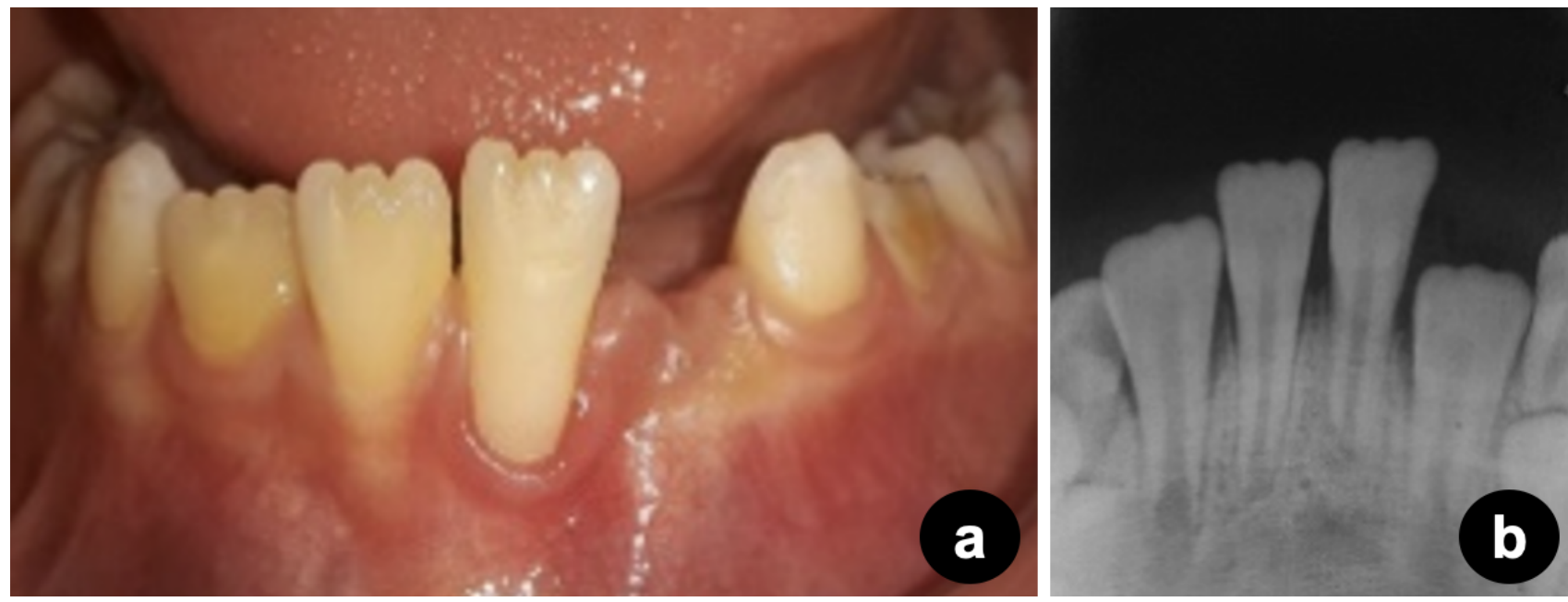

Figure 1. a: Preoperative view of Case 1 b: Preoperative radiograph showing extruded tooth.

and the damage of the apical neurovascular bundle. The healing process is stimulated through the reorganization of PDL and the regeneration of the vascular and nerve connections of the pulp. ${ }^{7,11}$ Lee et al. ${ }^{12}$ reported that pulp necrosis was experienced in $43 \%$ of extruded teeth. Endodontic treatments may be required in cases where pulpal pathologies are observed.

Root fractures, which constitute $0.5-7 \%$ of injuries in permanent dentition, are defined as those that involve cementum, dentine, and pulp. ${ }^{7}$ The location of the fracture line can be observed at coronal, middle or apical third. ${ }^{13}$ It has been shown that three healing modalities are considered for root fractures: hard tissue healing, connective tissue healing, and non-healing with granulation tissue. ${ }^{7}$

The primary goal of the treatment of TDI is to provide stabilization by correct diagnosis in the early stage. Treatment approaches vary depending on the vitality of the pulp, the position of the tooth, the age of the patient, and the stage of root development. ${ }^{14}$ When the root canal treatment is required, calcium silicate-based root canal filling materials promise successful results considering their advantages such as impermeability, biocompatibility, and dimensional stability. ${ }^{15}$ This case series aimed to present treatment plans and 2-year follow-up of upper and lower anterior teeth with different late-admitted traumatic dental injuries.

\section{Case Reports}

\section{Case 1}

An 8-year-old male patient consulted with the Department of Pediatric Dentistry with a complaint of mobility in teeth. It was learned that the patient had a bicycle accident 20 days prior and no treatment was applied in the meantime. Intraoral examination revealed mobility in tooth \#31, gingival recession, and negative response to cold sensitivity test (Chloraethyl, Wehr, Germany) and a displacement of $2 \mathrm{~mm}$ along the axis (Figure 1a). Radiographic examination showed altered periodontal ligament space and immature root with open apex. The tooth \#31 was diagnosed as extrusion (Figure 1b).

Due to late clinical admission, the tooth \#31 could not be repositioned because the socket was not appropriate. A semirigid splint was applied between teeth \#33 and \#43 for 14 days and regenerative endodontic treatment was performed to \#31. The protocol of the American Association of Endodontists was used as described below ${ }^{16}$, the tooth was isolated with a rubber dam and the access cavity was prepared. The root canal was irrigated with $20 \mathrm{~mL} 1.5 \%$ sodium hypochlorite $(\mathrm{NaOCl})$ solution followed by $20 \mathrm{~mL}$ sterile saline and dried with paper points. Equal proportions of ciprofloxacin (Cipro Biofarma, Istanbul, Turkey) and metronidazole (Flagyl Eczacibasi, Istanbul, Turkey) were ground and mixed with sterile saline. This antibiotic paste was placed in the root canal below the cementoenamel junction using dental syringe. The access cavity was temporarily sealed with a sterile cotton pellet and restorative glass ionomer cement (Ionofil, Voco, Cuxhaven, Germany). After 3 weeks, the patient was asymptomatic. After applying a rubber dam, the access cavity was reopened, the antibiotic mixture was removed by irrigation with $20 \mathrm{~mL}$ sterile saline, 20 mL $17 \%$ EDTA and the root canal was dried with paper points Bleeding into root canal was created by over-instrumentation at $2 \mathrm{~mm}$ past the apical foramen. Coronal third of the root canal was sealed with Biodentine (Septodont, Saint Maur des Faussés, France) over the blood clot, the tooth was permanently restored with reinforced glass ionomer cement (Ketac ${ }^{\mathrm{TM}} \mathrm{Mo}-$ lar Easymix, 3M ESPE, Seefeld, Germany) and composite resin (Clearfil Majesty, Kuraray, Osaka, Japan).

In order to correct the anterior crossbite and to eliminate the occlusal trauma that may occur, vertical dimension of occlusion was increased by using inclined composite resin. When the upper anterior teeth reached a sufficient crown length, a removable appliance with the bite plane and labiolingual springs were used. The patient was recalled at 3-week intervals and the spring was activated. At the end of three months of treatment, the anterior crossbite was successfully corrected and gingival recession in tooth \#31 was eliminated (Figure 2).

In the clinical and radiological follow-ups, no symptoms were observed, the periodontium was radiographically normal (Figure $3 a-b$ ), and apical closure was observed at the $12^{\text {th }}$ month (Figure 3c). However, at the periapical radiograph taken at the $24^{\text {th }}$ month, there was evidence of pulp canal obliteration at tooth \#31 (Figure 3d). The patient is scheduled for further follow-up.

\section{Case 2}

A 13-year-old male patient was referred to the Department of Pediatric Dentistry with the complaint of loosening of tooth \#21. It was learned that the patient had a traffic accident 3 days earlier. Clinical examination revealed damage to the nose, lips and mouth mucosa and mobility in teeth \#11 and \#21 (Figure 4a). In periapical radiography, presence of slight radiolucency was observed in the periapical region of tooth \#11 and 

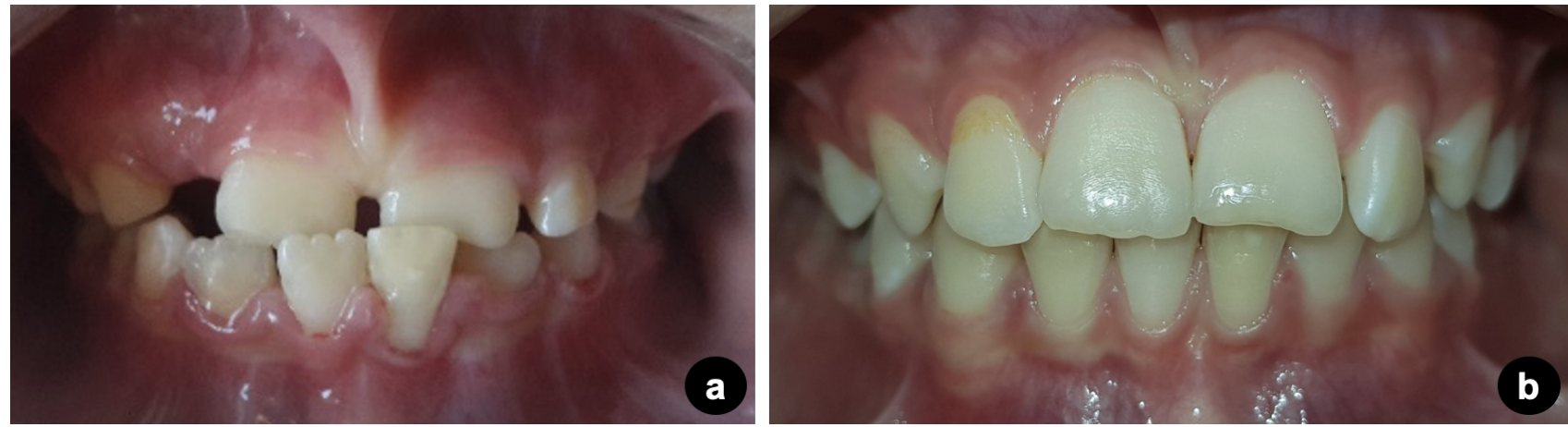

Figure 2. a: Pretreatment view of anterior crossbite. b: Intraoral photograph at the $24^{\text {th }}$ month.
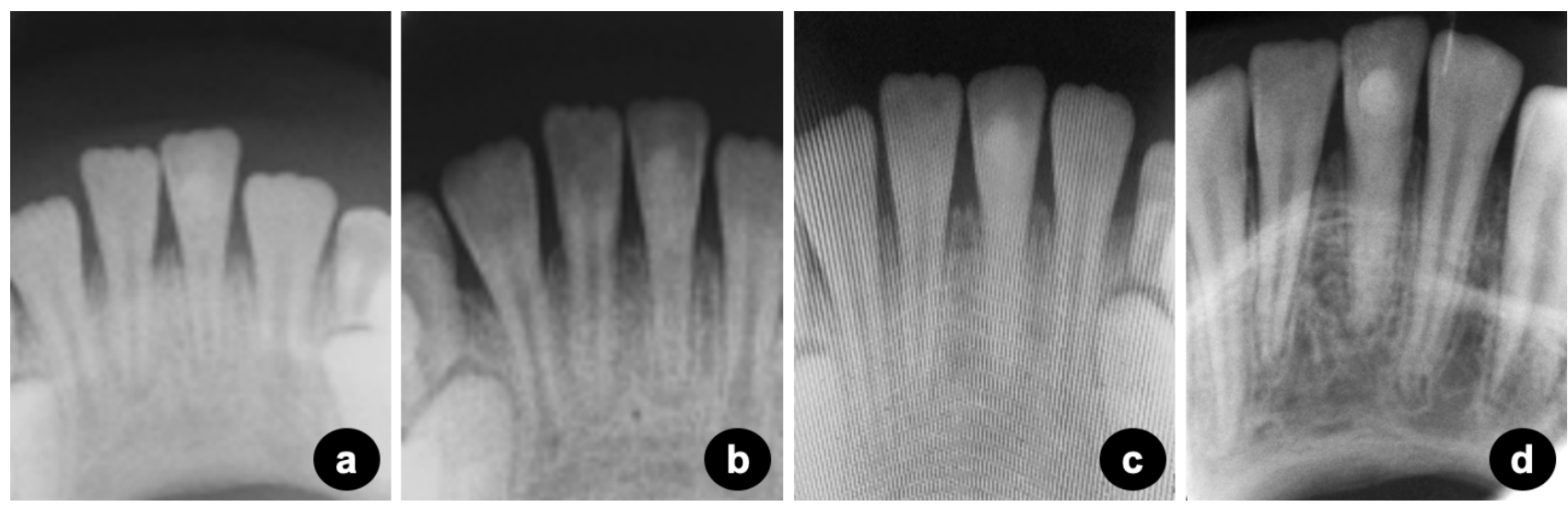

Figure 3. a:3-month follow-up radiograph. b: 6 -months follow-up radiograph. c: At the 12 -months follow-up, apical closure was evident. d: At the $24^{\text {th }}$ month, pulp canal obliteration at \#31 was observed.

diagnosed as subluxation; meanwhile horizontal root fracture was detected in the apical third of tooth \#21 (Figure $4 \mathrm{~b}$ ).

A semi-rigid splint was applied between teeth \#13 and \#23 for 4 weeks. Following a negative response to the cold sensitivity test on tooth \#21 in the second week, coronal part of the fracture line was considered as an immature tooth and root canal treatment was performed. The access cavity was prepared and the coronal pulp was removed. Root canal was instrumented and irrigated with $2.5 \% \mathrm{NaOCl}$, sterile salin. $\mathrm{CaOH}$ based root canal sealer (Kalsin, Aktu Tic, İzmir, Turkey) were placed into canals. After 3 weeks, permanent root filling was applied using Biodentine and the tooth was permanently restored with reinforced glass ionomer cement (Ketac ${ }^{\text {тм }} \mathrm{Mo}-$ lar Easymix, 3M ESPE, Seefeld, Germany) and composite resin (Clearfil Majesty, Kuraray, Osaka, Japan). At the $2^{\text {th }}$ month of the follow-up, after the diagnosis of pulp necrosis in tooth \#11, root canal treatment was initiated. Neo-MTA (Avalon Biomed Inc., Bradenton, FL, USA), which is a calcium silicate-based material, was used as permanent root filling material. In the clinical and radiographic controls at the $3^{\text {rd }}, 6^{\text {th }}, 12^{\text {th }}, 18^{\text {th }}$, and $24^{\text {th }}$ month, no symptoms were observed in the teeth, the fragments were healthy and no granulation tissue was formed in the tooth \#21 (Figure 5, Figure 6). The patient is scheduled for further follow-up.

\section{Discussion}

Parameters such as correct diagnosis, appropriate treatment timing and long-term follow-up in traumatized teeth are all known factors affecting the success of the treatment. ${ }^{17}$ Traumatic dental injuries are defined as an emergency that requires early intervention. ${ }^{18}$ Therefore, it is important that patients apply to the clinic at the appropriate time in order to increase the chances of success of the treatment.

In severe extrusion cases, early repositioning is a very important stage in the course of the treatment, whereas in Case 1, the late admission of the patient prevented the extruded tooth \#31 from being repositioned. It is thought that regeneration capacity will decrease as the probability of starting the process leading to pulp necrosis increases the possibility of damage to living tissues as a result of the severity of the trauma. ${ }^{19-21}$ However, successful results can be achieved by applying regenerative endodontic treatment in cases with traumatized teeth with open apex in late-admitted patients. ${ }^{22}$ For this reason, in the present case, regenerative endodontic treatment was preferred to the extruded tooth and it was observed that the apical closure was completed in the $12^{\text {th }}$ month.

In cases of root fractures, the success of the treatment depends on factors such as the severity of the trauma, the location of the fracture, the placement of the coronal part and the degree of root formation. Calcified tissue healing, which is the most ideal result, is possible by splinting the teeth as soon as possible and in a way that the broken parts match each other. ${ }^{23}$ However, if the fractured parts are separated from each other and the integrity of the pulp is disrupted as a result of the preintervention delay, the periodontal ligament cells initiate the healing process and hence, the fracture line joins with the connective tissue. ${ }^{11,16,24}$ Accordingly, in Case 2, who applied to the clinic 3 days after the trauma, it is thought that healing occurred with fibrous connective tissue in the fracture line in tooth \#21. It is reported that the apical fragment maintains vitality due to revascularization capability. ${ }^{25}$ In the present case, root canal treatment was applied only to the coronal part of tooth \#21, and no pathology was found in the apical part at the end of the 24-months follow-up period.

In addition to the correct diagnosis, appropriate treatment 

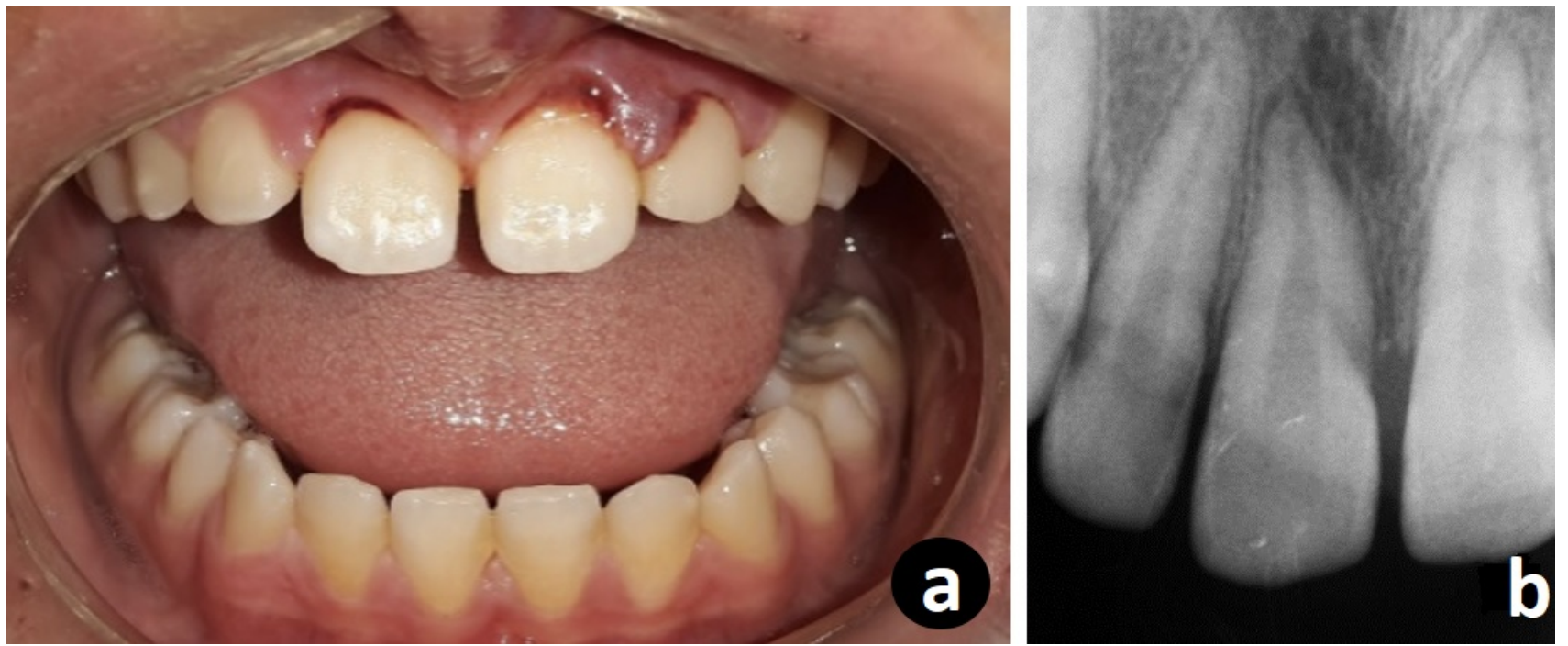

Figure 4. a:Preoperative view of Case 2. b: Preoperative radiograph showing horizontal fracture in the apical-third of the root of the tooth \#21.
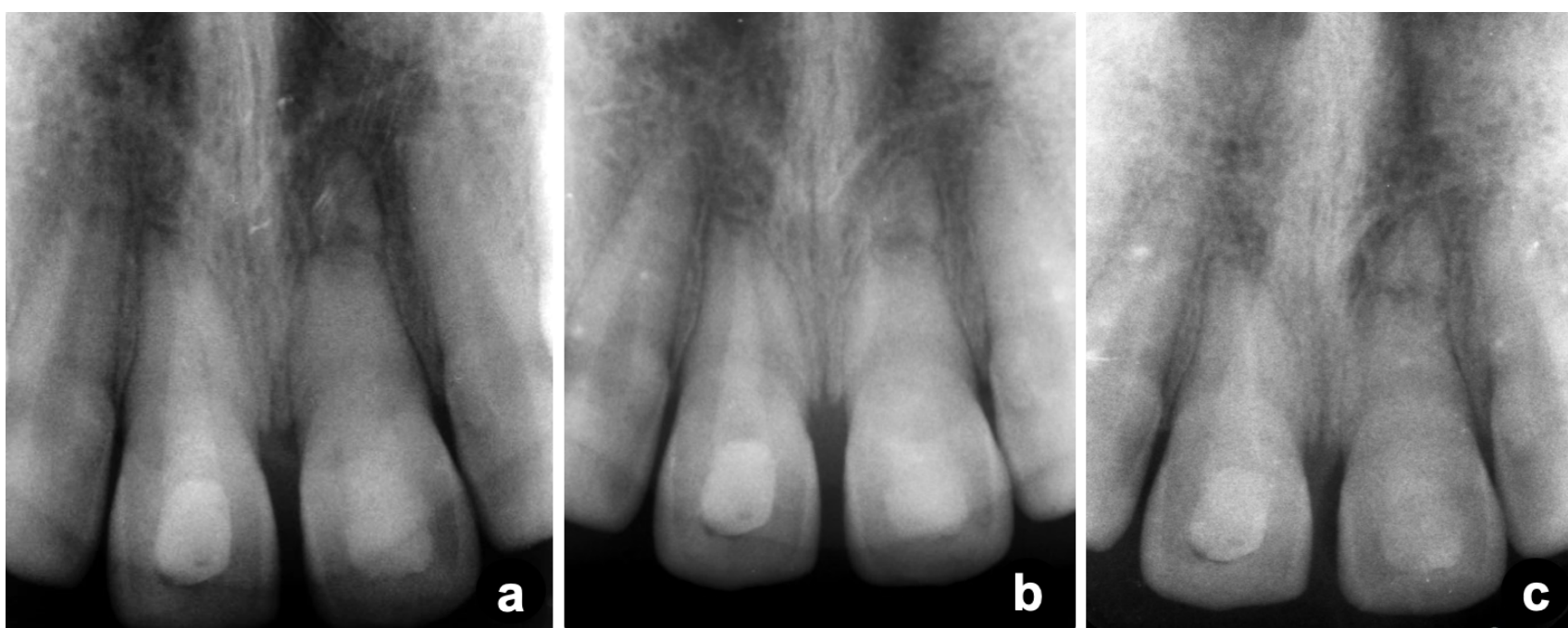

Figure 5. a:3-months follow-up radiograph after endodontic treatment. b:6-months follow-up radiograph. c:12-months follow-up radiograph.
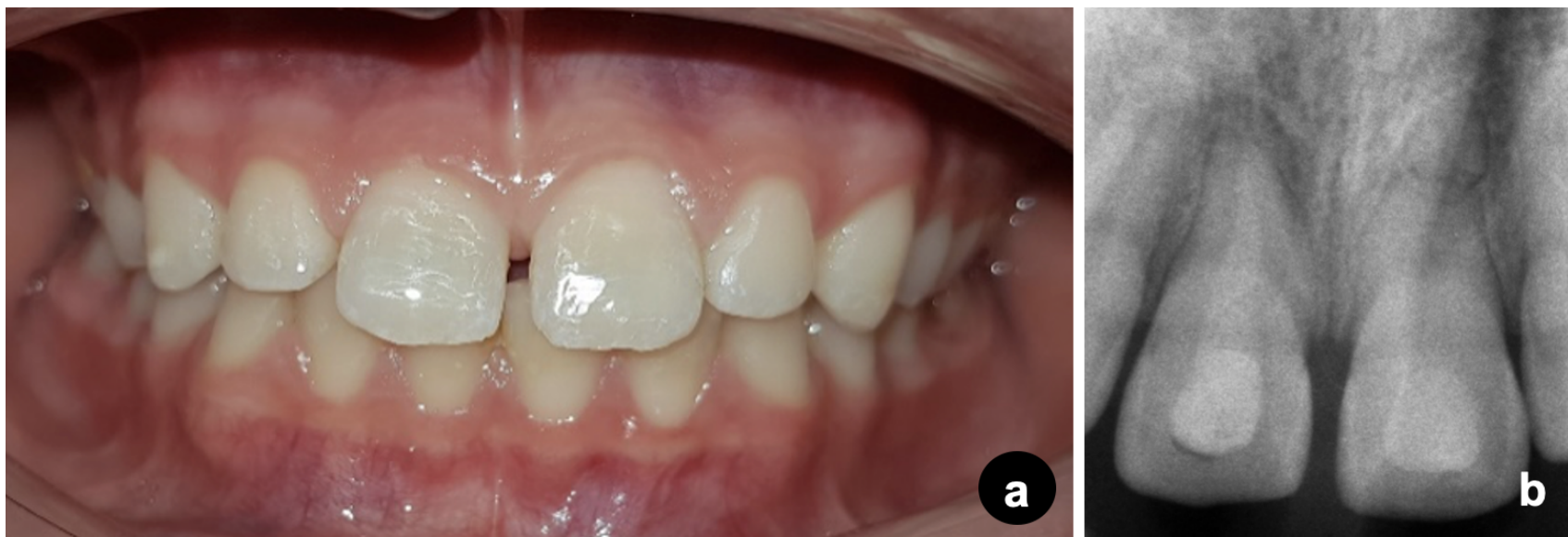

Figure 6. a:Intraoral photograph at the $24^{\text {th }}$ month. b: 24 -months follow-up radiograph. 
timing, clinical and radiological follow-up of the teeth is also necessary for early detection and treatment of complications that may occur after traumatic injuries. In the guideline published by the International Dental Traumatology Association, follow-up for at least 5 years is recommended for extrusion, intrusion and lateral luxation injuries in permanent teeth, also for crown/root fracture, root fracture, and alveolar fracture. The main complications that can be observed after trauma are defined as pulp necrosis and infection, pulp cavity obliteration and root resorption. ${ }^{17}$ Even if the symptoms are resolved in the short term, it is important that follow-ups take a long time, as complications may occur in the long term. As a matter of fact, it was found that root canal obliteration started in the $24^{\text {th }}$ month follow-up in Case 1, which was followed up despite apical closure observation at $12^{\text {th }}$ month. Andreasen ${ }^{23}$ reported that root canal obliteration is more common in teeth with incomplete root development than in teeth with complete root development, and in extrusion, lateral luxation, and intrusion injuries. In addition, it is thought that the stimulation of osteogenic cell formation ${ }^{24}$ as a result of Ca ion release from Biodentine, a calcium silicate-containing material, may be one of the reasons for root canal obliteration. The primary goal of regenerative endodontic treatments has been identified as symptom relief and bone healing, while the secondary goal is the thickening of the dentin walls, lengthening of the root length and apex closure. ${ }^{16}$ In addition to achieving these goals, it was decided that clinical and radiographic follow-up should continue due to the tooth being clinically asymptomatic and because of the absence of symptoms of a progressive infection in periapical tissues and. Aesthetic concerns should also be considered in anterior teeth. Since the components of MTA have been reported to cause discoloration of dental tissue, ${ }^{26}$ a number of clinical techniques are recommended prior to the use of this material. ${ }^{27}$ In recent years, materials containing calcium silicate such as Neo-MTA containing tantalum oxide and Biodentine with zirconium oxide have been developed as an alternative to the aforementioned components and studies have shown that these materials do not lead to discoloration of tooth. ${ }^{28}$ Biodentine and Neo-MTA, which have proven successful in this respect, were used in Case 1 and in both teeth in Case 2. In Case 2, the possible effects of the materials on success could thus be followed. Similarly, in both cases presented in this study, no clinical discoloration was observed at the end of the 24-months follow-up.

\section{Conclusion}

In this case series, treatment options of late-admitted traumatized permanent anterior teeth and prognosis in long term are presented. The prognosis of the tooth is affected by the type of the injury, treatment delay and the root development of tooth. In trauma cases, properly-timed endodontic treatments play a very important role in success. It should be kept in mind that satisfactory results can be obtained with regenerative endodontic treatment, which has many advantages over apexification or de-vital canal treatment options, even in late-admitted cases. Another factor that will affect the success is that the materials planned to be used in endodontic treatments can serve biological purposes, have appropriate clinical results due to their use in aesthetic areas and have easy-to-apply features. In order to provide the patient with satisfactory results in terms of aesthetics, phonation and function, correct treatment plan and regular follow-ups are of vital importance.

\section{Acknowledgements}

These case reports were previously presented as posters at the $26^{\text {th }}$ International Congress of Turkish Society of Pediatric Dentistry (10-13 October 2018) and International Meandros Dental Congress (23-25 November 2018).

\section{Author Contributions}

C.Ç and N.Ö conceived the ideas; C.Ç, B.N.Y and N.Ö collected and analyzed the data; C.Ç, B.N.Y and N.Ö led the writing.

\section{Conflict of Interest}

The authors declare no conflict of interest related to this study.

\section{Authors' ORCID(s)}

C.C.. $\quad 0000-0002-0641-0831$

B.N.Y. $0000-0002-8133-6627$

N.Ö. $\quad 0000-0003-4192-2960$

\section{References}

1. Zaleckiene V, Peciuliene V, Brukiene V, Drukteinis S. Traumatic dental injuries: etiology, prevalence and possible outcomes. Stomatologija. 2014;16(1):7-14.

2. Alhaddad B, Rózsa N, Tarján I. Dental trauma in children in Budapest. A retrospective study. Eur J Paediatr Dent. 2019;20(2):111-115. doi:10.23804/ejpd.2019.20.02.05.

3. Glendor $U$. Epidemiology of traumatic dental injuries-a 12 year review of the literature. Dent Traumatol. 2008;24(6):603-11. doi:10.1111/j.16009657.2008.00696.x.

4. Petti S, Glendor U, Andersson L. World traumatic dental injury prevalence and incidence, a meta-analysis-One billion living people have had traumatic dental injuries. Dent Traumatol. 2018;34(2):71-86. doi:10.1111/edt.12389.

5. Faus-Damiá M, Alegre-Domingo T, Faus-Matoses I, Faus-Matoses V, Faus-Llácer VJ. Traumatic dental injuries among schoolchildren in Valencia, Spain. Med Oral Patol Oral Cir Bucal. 2011;16(2):e292-5. doi:10.4317/medoral.16.e292.

6. Organization WH. Application of the international classification of diseases to dentistry and stomatology. 3rd ed. World Health Organization; 1994.

7. Andreasen JO, Andreasen FM, Andersson L. Textbook and color atlas of traumatic injuries to the teeth. John Wiley \& Sons; 2018.

8. de Souza BDM, Dutra KL, Reyes-Carmona J, Bortoluzzi EA, Kuntze MM, Teixeira CS, et al. Incidence of root resorption after concussion, subluxation, lateral luxation, intrusion, and extrusion: a systematic review. Clin Oral Investig. 2020;24(3):1101-1111. doi:10.1007/s00784-020-03199-3.

9. Fried I, Erickson P, Schwartz S, Keenan K. Subluxation injuries of maxillary primary anterior teeth: epidemiology and prognosis of 207 traumatized teeth. Pediatr Dent. 1996;18:145-151.

10. Pedrini D, Panzarini SR, Tiveron ARF, Abreu VMd, Sonoda CK, Poi WR, et al. Evaluation of cases of concussion and subluxation in the permanent dentition: a retrospective study. J Appl Oral Sci. 2018;26. doi:10.1590/1678-77572017-0287. 
11. Andreasen JO, Bakland LK, Flores MT, Andreasen FM, Andersson L. Traumatic dental injuries: a manual. John Wiley \& Sons; 2011.

12. Lee R, Barrett EJ, Kenny DJ. Clinical outcomes for permanent incisor luxations in a pediatric population. II. Extrusions. Dent Traumatol. 2003;19(5):274-279. doi:10.1034/j.1600-9657.2003.00208.x.

13. Ranka M, Shah J, Youngson C. Root fracture and its management. Dent Update. 2012;39(8):530-538. doi:10.12968/denu.2012.39.8.530.

14. Moule A, Cohenca N. Emergency assessment and treatment planning for traumatic dental injuries. Aust Dent J. 2016;61 Suppl 1:21-38. doi:10.1111/adj.12396.

15. Ishwarya $\mathrm{R}$, Arangannal $\mathrm{P}$, Jeevarathan J, Vijayakumar $M$, Aarthi J, Amudha S. Application Of Mta And Biodentine In Pediatric Endodontics: A Review. EJMCM. 2020;7(2):65096515.

16. AAE Clinical Considerations for a Regenerative Procedure [Web Page]; 2018. Available from: https: //www.aae.org/specialty/wp-content/uploads/sites/2/ 2018/06/ConsiderationsForRegEndo_As0fApril2018.pdf.

17. 2020 IADT Guidelines for the Evaluation and Management of Traumatic Dental Injuries [Web Page]; 2020. Available from: https://www.iadt-dentaltrauma.org/ for-professionals.html.

18. Karaalioğlu E, Bani M, Öztaş N. Anterior çapraz kapanışlı olguda çoklu dental travma: iki yll takipli olgu raporu. J Dent Fac Atatürk Uni. 2015;25(1). doi:10.17567/dfd.56573.

19. Kahler B, Mistry S, Moule A, Ringsmuth AK, Case P, Thomson A, et al. Revascularization outcomes: a prospective analysis of 16 consecutive cases. J Endod. 2014;40(3):3338. doi:10.1016/j.joen.2013.10.032.

20. Lin J, Zeng Q, Wei X, Zhao W, Cui M, Gu J, et al. Regenerative Endodontics Versus Apexification in Immature Permanent Teeth with Apical Periodontitis: A Prospective Randomized Controlled Study. J Endod. 2017;43(11):1821-1827. doi:10.1016/j.joen.2017.06.023.

21. Nosrat A, Homayounfar N, Oloomi K. Drawbacks and unfavorable outcomes of regenerative endodontic treatments of necrotic immature teeth: a literature review and report of a case. J Endod. 2012;38(10):1428-34. doi:10.1016/j.joen.2012.06.025.

22. Kuşgöz A, Yahyaoğlu G. Travmaya Uğramış Nekrotik Pulpalı Genç Daimi Yan Keser Dişte Pulpa Revaskülarizasyonu: 48 Aylık Takip. Turkiye Klinikleri J Pediatr Dent. 2016;2(1):28-32.

23. Andreasen FM, Zhjie Y, Thomsen BL, Andersen PK. Occurrence of pulp canal obliteration after luxation injuries in the permanent dentition. Dent Traumatol. 1987;3(3):103115. doi:10.1111/j.1600-9657.1987.tboo611.x.

24. Bonson S, Jeansonne B, Lallier T. Root-end filling materials alter fibroblast differentiation. J Dent Res. 2004;83(5):408-413. doi:10.1177/154405910408300511.

25. Girelli CF, de Lima CO, Lacerda MF, Coellho RG, Silveira $\mathrm{FF}$, Nunes $\mathrm{E}$. The importance of bioceramics and computed tomography in the late clinical management of a horizontal root fracture: A case report. J Clin Exp Dent. 2020;12(5):e514-e518. doi:10.4317/jced.56585.

26. Marciano MA, Costa RM, Camilleri J, Mondelli RF, Guimarães BM, Duarte MA. Assessment of color stability of white mineral trioxide aggregate angelus and bismuth oxide in contact with tooth structure. J Endod. 2014;40(8):1235-40. doi:10.1016/j.joen.2014.01.044.

27. Choi YL, Jang YE, Kim BS, Kim JW, Kim Y. Preapplication of dentin bonding agent prevents discoloration caused by mineral trioxide aggregate. BMC Oral Health. 2020;20(1):163. doi:10.1186/s12903-020-01151-1.

28. Madani Z, Alvandifar S, Bizhani A. Evaluation of tooth discoloration after treatment with mineral trioxide aggregate, calcium-enriched mixture, and Biodentine( $\left.{ }^{\circledR}\right)$ in the presence and absence of blood. Dent Res J (Isfahan). 2019;16(6):377-383. doi:10.4103/1735-3327.270787. 